\title{
MARKKETING OF EDUCATION SERVICES: PROBLEMS AND PERSPECTIVES
}

\author{
S. Tkachuk, S. Stakhurska, V. Stakhurskiy \\ National University of Food Technologies
}

\begin{tabular}{l}
\multicolumn{1}{c}{ Key words: } \\
Marketing \\
Marketing of services \\
Marketing of educational \\
services \\
Educational services \\
Marketing-mix of \\
educational services \\
\hline
\end{tabular}

Article history:

Received 10.01.2018

Received in revised form

23.01.2018

Accepted 12.02.2018

Corresponding author:

S. Tkachuk

E-mail:

npnuht@ukr.net

\begin{abstract}
Problems and perspectives of forming the competitive educational service, considering two markets: market of educational services and labor market are analyzed. The main features of classical and innovational approaches to provision of educational services are investigated and systematized. The existing disadvantages of the classical approach are filtered out, the ways of their elimination are proposed. The main advantages of the classical approach are highlighted and proposed to combine with innovative methods. The main stages of formation of marketing strategy of educational institutions are highlighted, the features of the strategy are analyzed. The features and factors of success of marketing-mix of educational institutions are formulated, taking into account the intangible component of the proposed product and specificities of education services. The marketing-mix of educational service is proposed to consider as the totality of seven interconnected elements: the classical four and the additional three that are inherent in the field of intangible production. The description of each element is presented and the interrelation among them is investigated. The basic principles of forming of a successful marketing-mix of educational institutions are described. The process of servicing during the provision of educational service is proposed to be considered in accordance with the model of service marketing SERVACTION as the interaction between contact personnel, each individual client and other clients in the material medium. The material medium of educational establishment is considered as the totality of three debugged systems: components that are related to the implementation of NTP, achievements in education, aesthetic components and components of comfort. The requirements for personnel are proposed to be classified according to two main features: professional and personal qualities. The organization of the process of providing educational services is considered in three dimensions: the process of interaction between contact personnel and clients, organization of the educational process in space and time, the process of providing accompanying and additional services.
\end{abstract}

DOI: $10.24263 / 2225-2924-2018-24-1-6$ 


\section{МАРКЕТИНГ ОСВІТНІХ ПОСЛУГ: ПРОБЛЕМИ ТА ПЕРСПЕКТИВИ}

\section{С.В. Ткачук, С.А. Стахурська, В.О. Стахурський}

Національний університет харчових технологій

У статті проаналізовано проблеми і перспективи формування конкурентоспроможної освітньої послуги з огляду двох ринків: ринку освітніх послуг та ринку прачі. Досліджено й систематизовано основні риси класичного та інноваційного підходів до надання послуг освіти. Відфільтровано наявні недоліки класичного підходу, запропоновано способи їх усунення. Виділено основні переваги класичного підходу, які пропонується поєднувати з інновачійними методами, та основні етапи формування маркетингової стратегії освітніх закладів, проаналізовано ії особливості. Сформульовано особливості та чинники успішності маркетинг-міксу освітніх закладів $з$ урахуванням нематеріальної складової продукту, який пропонується, а також специффіки послуг освіти. Маркетинговий комплекс освітньої послуги пропонується розглядати як сукупність семи взаємопов'язаних між собою елементів: чотирьох класичних, трьох додаткових, таких, що притаманні нематеріальній сфері. Описано кожен елемент, досліджено взаємозв'язок між ними. Визначено основні принципи формування успішного маркетингового комплексу закладів освіти.

Прочес обслуговування при наданні освітньої послуги пропонується розглядати як модель маркетингу послуг SERVACTION, взаємодію контактного персоналу, кожного окремо взятого клієнта та інших клієнтів у матеріальному середовищі. Матеріальне середовище закладу освіти розглядається як сукуnність трьох налагоджених систем: складових, пов'язаних із впровадженням в освіту досягнень НТП, естетичних складових і складових комфорту. Вимоги до персоналу пропонується класифікувати за двома основними ознаками: за професійними та особистими якостями. Організація процесу надання освітньої послуги розглядається у трьох площинах: процес інтерактивної взаємодії міжс контактним персоналом та клієнтами, організаџія процесу освіти в просторі $і$ в часі, прочес надання супутніх і додаткових послуг.

Ключові слова: маркетинг, маркетинг послуг, маркетинг освітніх послуг, освітні послуги, маркетинг-мікс освітніх послуг.

Постановка проблеми. Маркетинг послуг $є$ відносно новим напрямом у науці, ще менш дослідженим залишається питання маркетингу у сфері освітніх послуг. При цьому питання створення конкурентоспроможної освітньої послуги є досить важливим, що пояснюється такими причинами: значною конкуренцією між вищими навчальними закладами (ВН3); зв'язком між якістю освітньої послуги та забезпеченням необхідних країні професіоналів, а також добробутом самих громадян; інтеграцією країни у міжнародний простір, що зумовлює необхідність нового погляду на якість освіти; взаємовідносинами між ВНЗ та органами державної влади, зокрема щодо виділення 
необхідної кількості держбюджетних місць; значним впливом макроекономічних чинників на маркетингову стратегію ВНЗ тощо. Тенденціями сьогодення, що спостерігаються у сфері освіти, є так звана «боротьба» між «старими» (класичними) та «новими» підходами до навчання. Важливим при цьому $€$ формування такої освітньої послуги, яка б поєднувала у собі переваги обох підходів і максимально задовольняла вимоги ринку. Для досягнення цієї мети необхідно перш за все ефективно виконати такі завдання:

1) розмежувати переваги та недоліки класичних підходів до навчання, ліквідувати недоліки, а переваги розвивати разом із «новими» підходами;

2) сформувати загальні вимоги до ефективного маркетинг-міксу освітньої послуги 3 урахуванням специфіки послуги як продукту та сучасних потреб ринку;

3) сформувати загальний підхід до розроблення маркетингової стратегії освітніх закладів.

Аналіз останніх досліджень і публікацій. Проблемам маркетингу освітніх послуг присвячені праці [1-12], у яких розглядаються специфічні риси освітньої послуги в аспекті особливостей послуги як товару, іiі невідчутності, невіддільності від джерела, непридатності до зберігання та мінливості [10], подається опис основних базових елементів маркетинг-міксу освітньої послуги [11], аналізуються перспективи застосування Інтернет-технологій у сфері освітніх послуг [8], досліджуються проблеми якості та параметрів сучасної освітньої послуги [7]. Водночас існує необхідність систематизації існуючих поглядів, детального розгляду додаткових елементів маркетингміксу освітньої послуги, а також подальшого дослідження проблем впровадження в освіту сучасних підходів до наукової комунікації.

Мета дослідження: систематизація та подальший розвиток існуючих підходів до формування конкурентоспроможної освітньої послуги і розроблення дієвого маркетингового комплексу у сфері освіти.

Викладення основних результатів дослідження. Якість освітніх послуг та їх відповідність ринковим вимогам багато в чому є запорукою успішного розвитку країни 3 погляду макро- та мікроекономіки, міжнародних взаємовідносин і соціального добробуту. Від якості освіти залежить рівень зайнятості, рівень інноваційного розвитку підприємств, промислова безпека держави та багато іншого, що пов'язано із забезпеченістю держави висококваліфікованими, затребуваними кадрами, з одного боку, та добробутом і психологічним станом кожного окремого індивіда -3 іншого. Розроблення ефективної маркетингової стратегії закладами освіти повинно базуватись на класичному алгоритмі стратегічного планування, враховувати специфіку послуги, що надається (рис. 1).

Так, на першому етапі визначаються цілі маркетингу, наступним кроком $\epsilon$ проведення стратегічного аналізу, виявлення й оцінка зовнішніх загроз та можливостей і внутрішніх сильних та слабких сторін. Потім, на основі визначення й аналізу стратегії освітнього закладу за методом SWOT, мета та цілі можуть бути під кореговані. Після цього необхідно розробити дієву стратегію STP-маркетингу та, відповідно до неї, сформувати маркетинговий комплекс. 


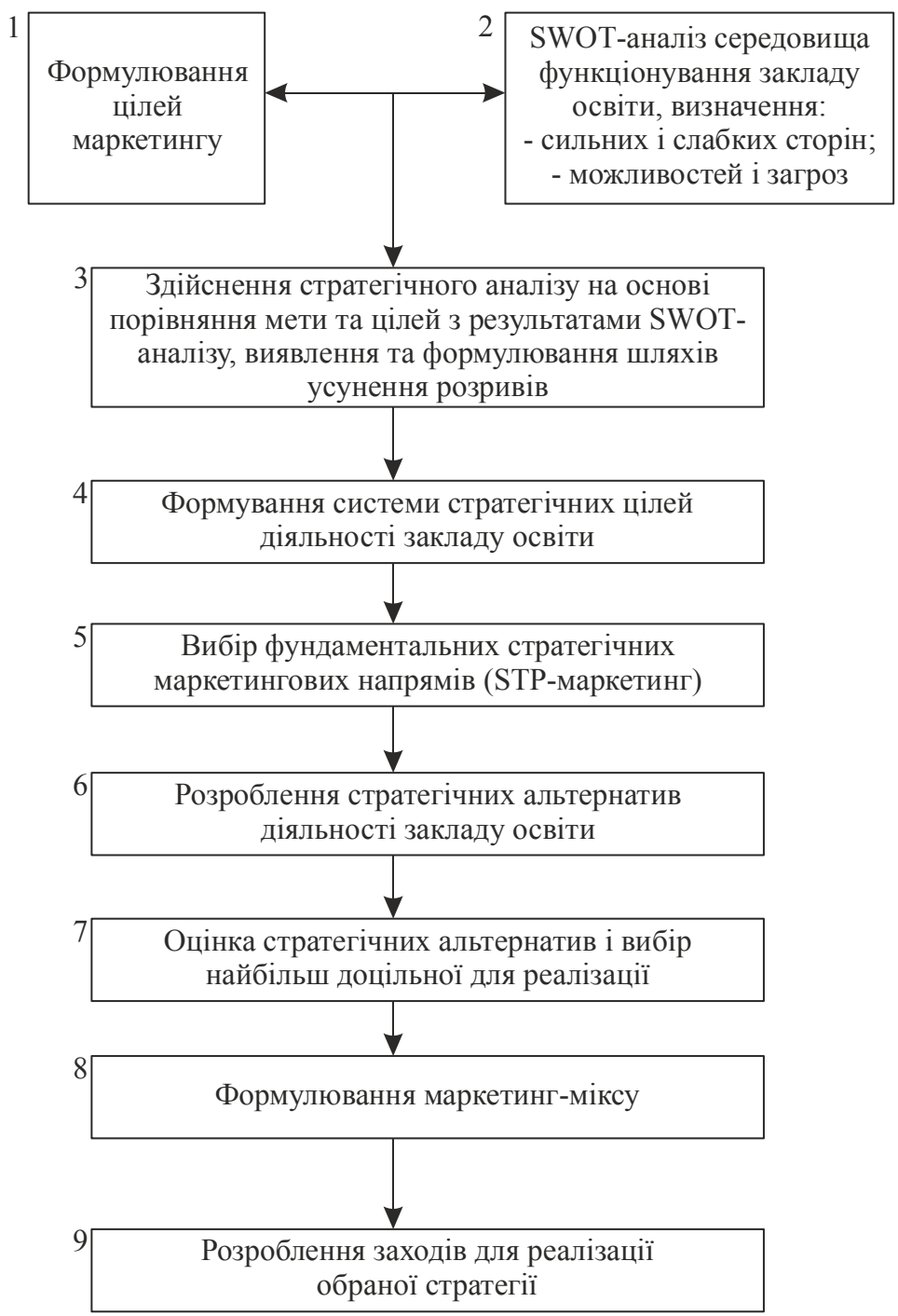

Рис. 1. Алгоритм формування маркетингової стратегї̈ закладу освіти

Слід враховувати і той факт, що формування стратегії STP ускладнюється неоднозначністю сегмента, на який орієнтована освітня послуга. Йдеться про те, що людина у віці 16-18 років, на який, як правило, припадає вибір освітнього закладу і спеціальності взагалі, не завжди може здійснити цей вибір правильно. Це пояснюється такими причинами: розрив між бажаною професією та реальними здібностями й можливостями, відсутність (у більшості випадків) попереднього досвіду роботи i, як результат, абстрактне уявлення про відповідність майбутньої спеціальності й типу роботи взагалі власним здібностям і бажанням. Значна роль у виборі ВНЗ, як правило, належить батькам чи опікунам абітурієнтів. 3 одного боку, це підвищує практичну складову вибору та його реальність, що $є$ позитивним, з іншого - зменшує 
участь абітурієнта у виборі власного шляху, що може в майбутньому негативно відобразитися на його задоволеності від отриманої професії. При розробленні маркетингових стратегії та комплексу маркетингу підприємство-виробник освітніх послуг має враховувати особливості сегменту молоді та середнього і старшого віку, які разом обирають освітній продукт. Це, зокрема, важливо під час формування елементів «просування» (засоби та джерела просування, тип рекламної стратегії, форма звернення), «фізичний доказ» (імідж і солідність ВНЗ, наявність працевлаштованих успішних випускників, грандів, сертифікатів тощо) та «матеріальне середовище» (солідне технічне оснащення, привабливе для молоді оформлення видимої частини процесу обслуговування тощо). Детальніше про особливості маркетинг-міксу в освіті піде нижче. Перш ніж говорити про кожен елемент комплексу маркетингу, потрібно визначитись із так званими «новими» та «класичними» підходами до надання освітніх послуг, зробити їх узагальнення та систематизацію, виявити переваги й недоліки кожного підходу та врахувати результати при формуванні маркетинг-міксу. Основні риси «нових» і «класичних» тенденцій подані на рис. 2.

Інколи прийнято піддавати «старі» підходи жорсткій критиці. I це справедливо. Втім не варто дивитись на «стару» систему освіти лише 3 негативного боку. Натомість доцільно виділити ії переваги, які можуть поліпшити «нову» систему.

1. Теоретична база $\epsilon$ необхідним інструментарієм для подальшої практичної діяльності, а тому чіткі вимоги до iï засвоєння є необхідними у процесі навчання. При цьому необхідно дотримуватись таких вимог для усунення наявних недоліків «старої» освіти:

- чітке роз'яснення сутності теоретико-методичних положень, їх практичної значущості та зв'язку із реальністю;

- недопущення «сліпого» заучування студентом (учнем) теоретичного матеріалу без його розуміння;

- подача матеріалу у систематизованому, структурованому, доступному, стислому вигляді.

2. Класичний підхід до організації процесу навчання вирізнявся, зокрема, так званим «спокійним» темпом подачі матеріалу. 3 одного боку, це $\epsilon$ недоліком, адже, по-перше, не привчає молодь до стрімкого ритму життя, по-друге, може сприйматися споживачем (студентом) як нецікавий, «сумний» процес. 3 іншого боку, помірний темп подачі матеріалу сприяє кращому його засвоєнню за умови вмілого викладання. Тут необхідно знайти «золоту середину» вдалого поєднання мінімального занотовування основних положень та інтерактивної взаємодії викладача й студента, наявності елементів наочності, жвавих дискусій і пояснень. Особливо важливе завдання до контактного персоналу (викладача) має висуватись під час організації практичних занять та оцінювання студентів. Тут важливо застосовувати комбінацію класичних прийомів (проведення усних опитувань, обговорення питань теми, написання контрольних робіт виконання творчих завдань) та інноваційних, так званих динамічних прийомів (групові завдання, брейн-ринги, кейси). Це є важливим не лише з погляду якісної організації процесу надання освітньої послуги, але 
й 3 погляду майбутньої профорієнтації студентів. Виконуючи різнобічні типи завдань («групові динамічні», творчі, «класичні», розрахункові), їм буде легше зрозуміти, який тип роботи підійде у майбутньому (індивідуальні завдання чи активна робота в групах; «абстрактно-творча» сфера або професії, що вимагають чіткого слідування інструкціям).

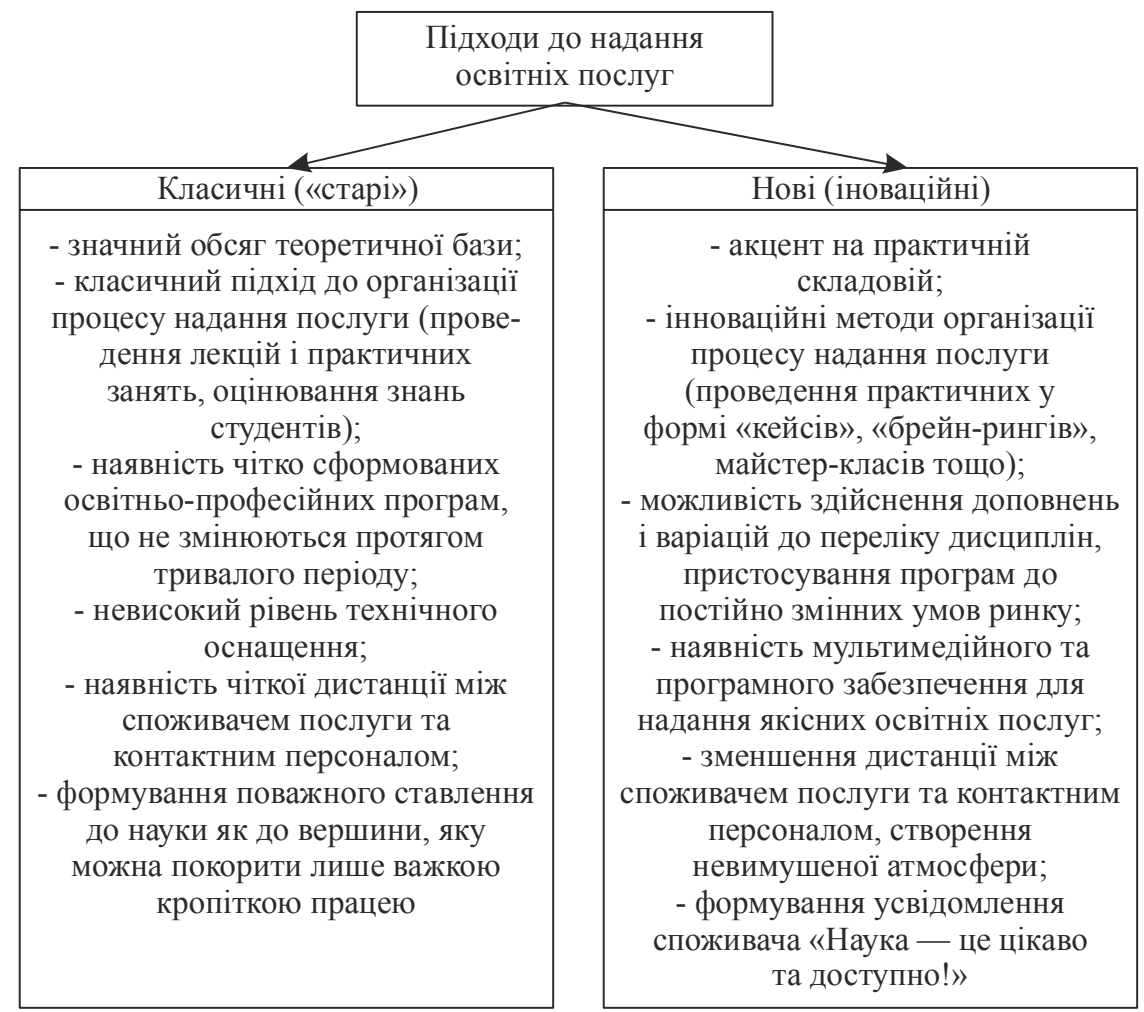

Рис. 2. Класичні та інноваційні тенденції у наданні освітніх послуг

3. Слабке технічне оснащення однозначно $є$ недоліком, що погано характеризує як процес надання послуги, так і матеріальне середовище освітнього закладу. Під час здобуття освіти 3 деяких видів спеціальностей відсутність відповідного програмного забезпечення може стати суттєвою перепоною для організації процесу навчання взагалі. Проте в інших випадках високий професійний рівень викладача міг частково знизити негативний ефект відсутності засобів наочності, що підтверджує важливість такого елемента маркетинг-міксу, як персонал. У «новій» системі організації процесу навчання мультимедійні технології повинні поєднуватись із високою професійністю контактного персоналу, застосуванням прийомів ефективної аргументації, правил підготовки презентацій тощо.

4. Ефект сприйняття вченого як надлюдини повинен бути замінений формуванням у студента розуміння практичної корисності та доступності науки, невимушена атмосфера у процесі здобуття освіти лише сприятиме кращому засвоєнню матеріалів і всебічного розвитку студента як особистості. Взаємини 
викладача та студента слід будувати 3 урахуванням основ маркетингу взаємовідносин, тобто рівності і взаємоповаги, як між бізнес-партнерами.

Усе вищеперераховане має бути покладено в основу маркетинг-міксу освітньої послуги, зокрема щодо елементів «процес», «персонал» і «матеріальне середовище». Пропонується розробляти комплекс маркетингу у сфері освіти в розрізі семи елементів, запропонованих М.Д. Бітнер для сфери послуг: класичних (товар, ціна, розповсюдження та просування) і додаткових, специфічних (матеріальне середовище, процес, персонал) (рис. 3).

При цьому слід пам' ятати такі правила:

- специфічні складові є не менш важливими за основні, їх недооцінка при формуванні маркетингових програм однозначно призведе до втрати конкурентних позицій;

- між усіма елементами маркетинг-міксу наявний складний багатофункціональний зв'язок і взаємовплив. Похибка та неврахування вимог ринку при формуванні одного 3 елементів, а також невідповідність між елементами можуть призвести до збою в цілій системі маркетинг-міксу;

- елементи «товар», «персонал» і «матеріальне середовище» чинять значний вплив і багато в чому формують елемент «процес».

\begin{tabular}{|c|c|c|c|c|c|}
\hline \multicolumn{6}{|c|}{ Основні складові } \\
\hline Товар & \multicolumn{2}{|r|}{ Ціна } & \multicolumn{2}{|c|}{ Розповсюдження } & Просування \\
\hline $\begin{array}{l}\text { Сукупність спе- } \\
\text { ціальностей, } \\
\text { що пропонуються } \\
\text { ВНЗ, і навчальні } \\
\text { плани за кожною } \\
\text { спеціальністю }\end{array}$ & \multicolumn{2}{|c|}{$\begin{array}{c}\text { Вартість послуг: } \\
\text { основних (освіт- } \\
\text { ніх, для контракт- } \\
\text { ників) } \\
\text { і додаткових } \\
\text { (проживання в } \\
\text { гуртожитку тощо) } \\
\end{array}$} & \multicolumn{2}{|c|}{\begin{tabular}{|c|} 
Наявність філіалів, \\
коледжів, можли- \\
вості дистанційно- \\
го навчання
\end{tabular}} & \begin{tabular}{|c|} 
Сукупність мерке- \\
тингових комуніка- \\
цій, що виконува- \\
тимуть інфор- \\
муючу, популяри- \\
заційну та іміджеву \\
функції \\
\end{tabular} \\
\hline \multicolumn{2}{|l|}{ Процес } & \multicolumn{2}{|c|}{ Персонал } & \multicolumn{2}{|c|}{ Матеріальне середовище } \\
\hline \multicolumn{2}{|c|}{\begin{tabular}{|c|} 
Організація процесу \\
надання освітніх послуг: \\
- безпосередньої взаємо- \\
дії споживача та \\
контактного персоналу; \\
- організація процесу \\
в часі та просторі
\end{tabular}} & \multicolumn{2}{|c|}{$\begin{array}{c}\text { Сукупність здібностей } \\
\text { та якостей контактного } \\
\text { персоналу, що необхідні } \\
\text { для надання конкуренто- } \\
\text { спроможних освітніх } \\
\text { послуг: } \\
\text { - професійних якостей; } \\
\text { - особистісних якостей }\end{array}$} & \multicolumn{2}{|c|}{\begin{tabular}{|c|} 
Матеріальна частина \\
процесу обслуговування: \\
- рівень технічного і \\
програмного \\
забезпечення; \\
- рівень естетичної \\
привабливості; \\
- рівень комфорту
\end{tabular}} \\
\hline \multicolumn{6}{|c|}{ Специфічні складові } \\
\hline
\end{tabular}

Рис. 3. Набір елементів маркетинг-міксу для освітньої послуги

Формуючи комплекс маркетингу освітньої послуги, необхідно враховувати специфіку такої послуги, а також специфічні риси самої спеціальності, менталітет майбутніх спеціалістів і вимоги не лише ринку освітніх послуг, 
але й ринку праці. У будь-якому разі, працюючи над елементами «персонал» $\mathrm{i}$ «процес», слід пам'ятати про Customer-relationships marketing та навіть впроваджувати систему Love-маркетингу [6].

Детальніше про специфіку кожного елемента та правила їх успішного формування йдеться нижче (табл.).

\section{Таблиџя. Специфіка і підходи до формування елементів маркетинг-міксу освітніх послуг}

\begin{tabular}{|c|c|}
\hline $\begin{array}{c}\text { Елемент } \\
\text { комплексу } \\
\text { маркетингу }\end{array}$ & Специфіка і підходи до формування \\
\hline 1 & 2 \\
\hline Товар & $\begin{array}{c}\text { Специфіка товару освітньої послуги - у його нематеріальності. Під } \\
\text { ним слід розуміти перелік спеціальностей, які пропонує ВНЗ, а в межах } \\
\text { кожної спеціальності - перелік дисциплін, які викладатимуться сту- } \\
\text { дентам. } 3 \text { метою підвищення попиту на освітню послугу під час форму- } \\
\text { вання товарної політики необхідно керуватись такими положеннями: } \\
\text { - наявність професійно спрямованих дисциплін уже з перших курсів } \\
\text { навчання; } \\
\text { - формування навчальних планів і програм дисциплін з урахуванням } \\
\text { вимог ринку праці; } \\
\text { - підвищення частки практичної підготовки студентів. }\end{array}$ \\
\hline Ціна & $\begin{array}{c}\text { Ціна на освітні послуги повинна формуватись з урахуванням таких } \\
\text { умов: } \\
\text { - рівня унікальності послуги; } \\
\text { - рівня конкуренції між ВНЗ; } \\
\text { - функціонально-інструментальної якості обслуговування. }\end{array}$ \\
\hline Розповсюдження & $\begin{array}{c}\text { Розповсюдження освітньої послуги може здійснюватись такими } \\
\text { шляхами: } \\
\text { - створення філій, коледжів та інших структурних частин ВНЗ } \\
\text { у містах країни; } \\
\text { - створення дистанційних курсів. }\end{array}$ \\
\hline Просування & $\begin{array}{c}\text { Покликане виконувати інформуючу, популяризаційну та іміджеві } \\
\text { функції. Засоби просування: } \\
\text { - Інтернет-маркетинг (просування через соцмережі, } \\
\text { створення та розкрутка сайтів, застосування SEO-технологій, } \\
\text { вірусний маркетинг тощо); } \\
\text { - івент-маркетинг (проведення цікавих заходів, подій, } \\
\text { майстер-класів, днів відкритих дверей — із подальшою популяризацією } \\
\text { подій засобами Інтернет-маркетингу). }\end{array}$ \\
\hline Процес & $\begin{array}{c}\text { Організація процесу надання освітньої послуги: } \\
\text { - організація безпосереднього процесу обслуговування (процесу } \\
\text { інтерактивної взаємодії, учасниками якої є викладач, кожен окремий } \\
\text { студент та інші студенти у матеріальному середовищі); } \\
\text { - організація процесу надання освітньої послуги в просторі } \\
\text { та в часі (розподіл аудиторного фонду, тривалість і чергування часу } \\
\text { праці та відпочинку, зручний розподіл чергування лекційних } \\
\text { і практичних занять тощо); } \\
\text { - організація надання супутніх і додаткових послуг } \\
\text { (послуг проживання у гуртожитку, харчування, розважальні послуги, } \\
\text { банківські послуги (оплата за навчання й отримання стипендій) тощо). }\end{array}$ \\
\hline
\end{tabular}




\begin{tabular}{|c|c|}
\hline & Продовження таблииі \\
\hline 1 & C \\
\hline Персонал & $\begin{array}{c}\text { Основним контактним персоналом для споживача освітньої послуги є } \\
\text { викладач. До нього висувається перелік таких вимог: } \\
\text { - щодо професійних якостей: } \\
\text { - обізнаність у предметах, що викладаються; } \\
\text { - наявність практичної підготовки, орієнтація у сучасних тенденціях } \\
\text { у розрізі дисципліни, що викладається; } \\
\text { - високий рівень ораторського мистецтва; } \\
\text { - застосування прийомів ефективної аргументації; } \\
\text { - вміння інтерактивної взаємодії з групами, ведення дискусій тощо; } \\
\text { - щодо особистісних якостей: } \\
\text { - ввічливість, пунктуальність, повага до студента; } \\
\text { - доброзичливе ставлення; } \\
\text { - індивідуальний підхід до студента; } \\
\text { - базове розуміння психології особистості; }\end{array}$ \\
\hline $\begin{array}{l}\text { Матеріальне } \\
\text { середовище }\end{array}$ & $\begin{array}{c}\text { Видима для споживача матеріальна частина процесу обслуговування } \\
\text { повинна розглядатись принаймні з трьох ракурсів: } \\
\text { - матеріальні складові, пов'язані з впровадженням у навчання } \\
\text { інновацій науково-технічного прогресу (наявність і доступність } \\
\text { мультимедійного обладнання; інноваційне програмне забезпечення; } \\
\text { сучасна комп’ютерна техніка; наявність Wi-Fi тощо); } \\
\text { - матеріальні складові, пов’язані з підвищенням рівня естетичної } \\
\text { привабливості (приємна кольорова гама, охайність аудиторій, } \\
\text { привабливе оформлення студзони покликані позитивно впливати на } \\
\text { самопочуття споживача, сприяти позитивній атмосфері); } \\
\text { - матеріальні складові, покликані підвищити рівень комфорту } \\
\text { споживача (зручність стільців і парт, приємне освітлення, наявність } \\
\text { жалюзі (на випадок надмірного сонячного світла), утеплення вікон } \\
\text { взимку та достатнє опалення приміщень тощо). }\end{array}$ \\
\hline
\end{tabular}

При формуванні маркетинг-міксу освітньої послуги слід обов'язково враховувати основні засади наукових шкіл маркетингу послуг, які матимуть відображення і в сфері освіти:

1. Послуга $\epsilon$ невідривною від джерела надання й споживання, процес виробництва та споживання послуги збігаються в часі, а тому важлива роль повинна відводитись питанням інтерактивного маркетингу, тобто маркетингу взаємодії між контактним персоналом (викладачем) і споживачем (студентом). Через це зростає роль людського чинника і вимоги до персоналу підвищуються.

2. Елементи «персонал», «процес» і «матеріальне середовище» перебувають у постійному взаємозв'язку і разом із споживачами створюють процес обслуговування [4] або процес інтерактивної взаємодії споживача та контактного персоналу [4]. Ці три елементи $є$ не менш важливими, ніж перші чотири, класичні елементи маркетинг-міксу.

3. Якість освітньої послуги потребує всебічного сприйняття з урахуванням функціонально-інструментальної моделі якості обслуговування, запропонованої К. Грьонросом [1]. Інструментальна якість, яка відображає якість результату від отримання послуги, є менш прогнозованою, ніж у багатьох 
інших сферах. Це випливає із самої сутності результату освітньої послуги успішного працевлаштування. Останнє, у свою чергу, залежить від багатьох факторів, а не лише від якості освіти. Завданням виробника освітніх послуг максимальне врахування вимог ринку праці у розрізі пропонованих спеціальностей, а також внесення оперативних коректив в елементи маркетинг-міксу у разі змін вимог ринку. Завданням контактного персоналу також $\epsilon$ максимальне надання студентам практичних навичок і здійснення допомоги у майбутній профорієнтації. Інша складова якості освітніх послуг - функціональна - відповідає за якість процесу надання послуги. Тут значна роль належить персоналу та матеріальному середовищу, а також процесу обслуговування як такому. Ефективність трьох зазначених елементів формує високу функціональну якість освітньої послуги.

4. В основі конкурентоспроможної освітньої послуги лежить вдало налагоджене функціонування всіх зв'язків за «трикутником маркетингу послуг» Ф. Котлера [3]. Зовнішній маркетинг покликаний врахувати вимоги та кон'юнктуру ринку освітніх послуг та ринку праці і на основі цього сформувати ефективні маркетингові програми. Завданням внутрішнього маркетингу дослідження потреб працівників і розроблення ефективної системи мотивації. Останнє має призвести до дієвого інтерактивного маркетингу, коли висококваліфікований мотивований персонал забезпечуватиме якісний процес надання послуги.

\section{Висновки}

1. На основі виділення головних ознак класичного та інноваційного підходу до надання освітніх послуг можна зробити висновок про перевагу інноваційного підходу, втім класичний підхід також має позитивні риси, які повинні бути збережені і в новій системі.

2. Маркетинг-мікс у сфері освітніх послуг повинен включати в себе сім елементів, запропонованих М.Д. Бітнер: чотири - стандартні (товар, ціна, розповсюдження, просування), три - притаманні сфері нематеріального виробництва (процес, персонал, матеріальне середовище). Значна роль належить персоналу, який у процесі інтерактивної взаємодії із споживачами у матеріальному середовищі освітнього закладу формує високу функціональну якість послуги.

3. Загальна схема формування маркетингової стратегії освітнього закладу в цілому не відрізняється від стандартних схем. Основна специфіка має місце на етапі формування комплексу маркетингу з огляду на специфіку нематеріальної сфери взагалі та, зокрема, сфери освіти. Також потрібно враховувати специфіку цільових сегментів під час формування STP-стратегії.

\section{Література}

1. Grönroos C. Adopting a Service Logic for Marketing / C. Grönroos // Marketing Theory. 2006. — \# 6(3). - P. 317 - 333.

2. Завалько Н.А. Проблемы маркетинга образования в аспекте продвижения образовательных услуг / Н.А. Завалько // Вестник Омского университета. Серия «Экономика», № 3. - 2011. - C. 119-123. 
3. Котлер Ф. Маркетинг. Менеджмент: экспресс-курс // Ф. Котлер, К.Л. Келлер. Санкт-Петербург: Питер: Мир книг, 2012. - 479 с.

4. Красовська О.Ю. Моделі маркетингу послуг в системі управління сервісними організаціями / О.Ю. Красовська // Свропейський вектор економічного розвитку. - 2009. Вип. 1(6). - С. 52-58.

5. Лавлок К. Маркетинг услуг: персонал, технология, стратегия, 4-е изд. - Москва : Издательский дом «Вильямс», 2005. - 108 с.

6. Минина Т.Б. Love-маркетинг в системе высшего образования / Т.Б. Минина // Управленец № 7 - 8 (11-12). — 2010 [Электронный ресурс]. — Режим доступа : https://cyberleninka.ru/article/n/love-marketing-v-sisteme-vysshego-obrazovaniya.

7. Панкрухин А.П. Маркетинг образовательных услуг / А.П. Панкрухин // Из материалов Гильдии маркетологов //www.marketologi.ru [Электронный ресурс]. — Режим доступа: http://www.marketing.spb.ru/lib-special/branch/mou/2.htm.

8. Розова Н.В. Интернет-маркетинг в сфере образовательных услуг вуза / Н.В. Розова // Материалы XII Международной научно-практической конференции «Научное сообщество студентов XXI столетия. Междисциплинарные исследования». - Новосибирск, 2017 [Электронный ресурс]. - Режим доступа : https://sibac.info/studconf/science/xii/66687.

9. Сотникова Н.В. Особенности и специфика маркетинга образовательных услуг / Н.В. Сотникова // Социальная сеть работников образования nsportal.ru. — 2014. [Электронный ресурс]. - Режим доступа : https://nsportal.ru/detskiy-sad/upravleniedou/2014/12/17/osobennosti-i-spetsifika-marketinga-obrazovatelnykh-uslug-1.

10. Сударкина Х.В. Маркетинг образовательных услуг вуза: особенности, возможности, перспективы / Х.В. Сударкина [Электронный ресурс]. - Режим доступа : https://cyberleninka.ru/article/v/marketing-obrazovatelnyh-uslug-vuza-osobennosti-vozmozhnostiperspektivy.

11. Тугаев В.О. Особенности маркетинга образовательных услуг / В.О. Тугаев // Материалы XXX Международной научно-практической конференции «Научное сообщество студентов XXI столетия. Экономические науки». - Новосибирск, 2015 [Электронный ресурс]. - Режим доступа: https://sibac.info/studconf/econom/xxx/41161.

12. Шевченко Д.А. Маркетинг образовательных услуг / Д.А. Шевченко // Профессиональная социальная платформа для специалистов в рекламе и маркетинге Marketingpeople [Электронный ресурс]. — Режим доступа : http://marpeople.com/articles/253. 